\title{
Low birth weight leads to obesity, diabetes and increased leptin levels in adults: the CoLaus study
}

\author{
François R. Jornayvaz ${ }^{1}$, Peter Vollenweider ${ }^{2}$, Murielle Bochud ${ }^{3}$, Vincent Mooser ${ }^{4}$, Gérard Waeber ${ }^{2}$ \\ and Pedro Marques-Vidal ${ }^{*}$
}

\begin{abstract}
Background: Low birth weight is associated with increased rates of obesity, insulin resistance and type 2 diabetes, but the precise mechanisms for this association remain unclear. We aimed to assess the relationships between birth weight and markers of glucose homeostasis or obesity in adults.

Methods: Cross-sectional population-based study on 1458 women and 1088 men aged 35-75 years living in Lausanne, Switzerland. Birth weight was self-reported and categorized into $\leq 2.5,2.6-3.5,3.6-4.0$ and $>4.0 \mathrm{~kg}$. Body composition was assessed by bioimpedance. Leptin and adiponectin levels were measured by ELISA.

Results: Women with low birth weight $(\leq 2.5 \mathrm{~kg}$ ) had higher levels of fasting plasma glucose, insulin, HOMA, diabetes and metabolic syndrome; a non significant similar trend was seen in men. In both genders, height increased with birth weight, whereas a U-shaped association was found between birth weight and body mass index, waist circumference and body fat percentage. After adjusting for age, smoking status, physical activity and fat mass, an inverse association was found between leptin and birth weight categories: adjusted mean \pm standard error $17.3 \pm 0.7$, $16.2 \pm 0.3,15.6 \pm 0.5$ and $14.0 \pm 0.8 \mathrm{ng} / \mathrm{dL}$ for birth weight categories $\leq 2.5,2.6-3.5,3.6-4.0$ and $>4.0 \mathrm{~kg}$, respectively, in women $(p<0.05)$ and $9.8 \pm 0.8,9.1 \pm 03,7.8 \pm 0.4$ and $7.7 \pm 0.5 \mathrm{ng} / \mathrm{dL}$ in men $(p<0.05)$. An inverse association was also found between reported birth weight and leptin to fat mass ratio: mean \pm standard error $0.77 \pm 0.04$, $0.73 \pm 0.02,0.69 \pm 0.03$ and $0.62 \pm 0.04$ in women $(p<0.05) ; 0.46 \pm 0.05,0.45 \pm 0.02,0.39 \pm 0.02$ and $0.38 \pm 0.03$ in men $(\mathrm{p}<0.05)$. No differences in adiponectin levels were found between birth weight groups.

Conclusions: Middle-aged adults born with a low weight present a higher prevalence of diabetes and obesity and also higher leptin levels and leptin to fat mass ratio than adults born with a normal weight. The higher leptin levels and leptin to fat mass ratio among adults born with a low weight might be related to nutritional factors during childhood or to the development of leptin resistance and/or higher leptin production by body fat unit. Subjects born with a low weight should be counselled regarding the risks of developing diabetes and/or cardiovascular disease.
\end{abstract}

Keywords: Birth weight, Diabetes, Body composition, Leptin, Adiponectin, Cross-sectional study

\section{Background}

Low birth weight is associated with increased rates of obesity, insulin resistance and type 2 diabetes [1], which are components of the metabolic syndrome [2]. Albeit

\footnotetext{
*Correspondence: Pedro-Manuel.Marques-Vidal@chuv.ch

2 Department of Medicine, Department of Internal Medicine, Lausanne University Hospital, Lausanne, Switzerland

Full list of author information is available at the end of the article
}

the precise mechanisms for this association remain unclear, metabolic changes that could be related to alterations in body composition can be found already in childhood [3]. For instance, people with low birth weight present with higher plasma leptin concentrations than would be expected from their degree of obesity $[4,5]$. In children born with a low birth weight, leptin levels are increased after catch-up growth during childhood [6], but it is unclear what happens during later life. Further, 
it has been suggested that blood cord adiponectin levels are positively related with birth weight and BMI in newborns [7], with a subsequent increase in the risk of type 2 diabetes [8]; still, this statement has also been challenged [9]. Overall, whether leptin and adiponectin mediate the effects of low birth weight on obesity, insulin resistance and type 2 diabetes is unclear.

Altogether, to our knowledge, no study has ever assessed the associations between birth weight, diabetes and fat mass, and leptin or adiponectin levels in middle age people. Hence, in this study, we assessed the associations between birth weight, markers of glucose homeostasis, obesity, leptin and adiponectin levels using a cross-sectional, population-based study conducted in Lausanne, Switzerland.

\section{Subjects and methods Study population}

The CoLaus Study is a prospective population-based study aimed at assessing the prevalence and deciphering the molecular determinants of cardiovascular risk factors in the population of Lausanne, Switzerland, a town of 117,161 inhabitants, of which 79,420 are of a Swiss nationality. Its sampling procedure has been described previously [10]. Briefly, the complete list of Lausanne inhabitants aged 35-75 years was provided by the population registry of the city. A simple, non-stratified random sample of $35 \%$ of the overall population was drawn. Caucasian origin was defined as having both parents and grandparents born in a restricted list of countries (available from the authors). The following inclusion criteria were applied: (a) written informed consent; (b) aged 35-75 years and (c) willingness to take part in the examination and donate blood sample. Recruitment for the baseline survey began in June 2003 and ended in May 2006.

\section{Clinical data}

All participants attended the outpatient clinic of the University Hospital of Lausanne in the morning after an overnight fast. Data were collected by trained field interviewers in a single visit lasting about $60 \mathrm{~min}$.

Body weight and height were measured with participants standing without shoes in light indoor clothes. Body weight was measured in kilograms to the nearest $100 \mathrm{~g}$ using a Seca ${ }^{\circledR}$ scale, which was calibrated regularly. Height was measured to the nearest $5 \mathrm{~mm}$ using a Seca ${ }^{\circledR}$ height gauge. BMI was defined as weight $(\mathrm{kg})$ divided by height $(\mathrm{m})$ squared. Overweight and obesity were defined as previously described [11]. Waist circumference was measured with a non-stretchable tape over the unclothed abdomen at the mid-point between the lowest rib and the iliac crest. Two measures were made and the mean (expressed in $\mathrm{cm}$ ) used for analyses. Abdominal obesity was defined as a waist circumference $\geq 88 \mathrm{~cm}$ for women and $\geq 102 \mathrm{~cm}$ in men.

Fat and fat-free mass (in percent of total body weight) were assessed by electrical bioimpedance in the lying position after a 5 -min rest using the Bodystat ${ }^{\circledR} 1500$ body mass analyzer (Bodystat Ltd, Isle of Man, England). This device has been shown to correlate well $(r=0.968)$ with measurements from dual energy $\mathrm{X}$-ray absorptiometry (DEXA) [12]. In a subset of 794 women who were also screened for osteoporosis using DEXA, the correlation between fat mass estimated by bioimpedance and DEXA was $0.852(\mathrm{p}<0.001)$, with only a slight overestimation by BIA relative to DEXA $(+0.9 \mathrm{~kg})$. Participants had to be fasting, avoid strenuous physical activity during the previous $12 \mathrm{~h}$ and abstain from consuming caffeine or alcohol-containing beverages during $24 \mathrm{~h}$ before the analysis. All metallic adornments were removed, and measurement was performed after a 10-min rest in the lying position. The electrodes were positioned in the right side of the body according to the manufacturer's instructions. Care was taken to ensure that the participants did not touch any metallic component of the bed and that the inner part of the thighs did not touch each other. Results were expressed as (\%BF) and body fat mass was calculated as weight $\mathrm{x} \% \mathrm{BF}$ and expressed in $\mathrm{kg}$.

Weight at birth was asked to all participants and expressed in $\mathrm{kg}$. Four birth weight categories were created: $\leq 2.5,2.6-3.5,3.6-4.0$ and $>4.0 \mathrm{~kg}$. No information regarding gestational age at birth, term or preterm birth was collected. Smoking status was classified as never, former and current smokers. A participant was considered as physically active if he/she practiced at least twice per week leisure-time physical activities with a minimal duration of $20 \mathrm{~min}$. Menopausal status in women was defined by a positive answer to the question "are you already menopaused?".

\section{Biological data}

Venous blood samples $(50 \mathrm{ml})$ were drawn in the fasting state. Fasting plasma glucose and insulin were measured, and the homeostasis model assessment index of insulin resistance (HOMA) was calculated [13]. High HOMA index was defined if $>2.6$. Diabetes was defined as fasting plasma glucose $\geq 7.0 \mathrm{mmol} / \mathrm{L}$ or presence of oral or injectable hypoglycaemic treatment. Metabolic syndrome was defined using the Third Adult Treatment Panel (ATP-III) criteria [2]. Total adiponectin was assessed by ELISA (R\&D Systems, Inc., Minneapolis, USA), with a maximum inter-assay coefficient of variation $(\mathrm{CV})$ of $8.3 \%$ and a maximum intra-assay CV of $8.3 \%$. Leptin was also assessed by ELISA (American Laboratory Products 
Company, Windham, USA) with a maximum inter-assay $\mathrm{CV}$ of $12.8 \%$ and a maximum intra-assay CV of $5.8 \%$.

\section{Statistical analyses}

Statistical analyses were conducted using Stata v.14 (Stata Corp, College Station, TX, USA) and stratified by gender. Descriptive results were expressed as number of participants and (percentage) or as mean \pm standard deviation. Bivariate analysis was conducted using Chi square test for categorical variables and using Student's t test or one-way analysis of variance (ANOVA) for quantitative values. For continuous variables, post hoc pairwise comparisons using the method of Scheffe were performed when the results of the ANOVA were statistically significant. Multivariable analysis was conducted using logistic regression for binary dependent variables, and the results were expressed as odds-ratio and (95\% confidence interval); for quantitative variables, multivariable ANOVA was used and the results were expressed as adjusted mean \pm standard error. The leptin to fat mass ratio was computed as previously described [14, 15]. Because leptin and adiponectin concentrations are skewed, natural $\log$ transformation was performed prior to analysis.

\section{Ethics, consent and permissions}

The CoLaus Study was approved by the Institutional Ethics Committee of the University of Lausanne. All participants gave their signed informed consent before entering the study.

\section{Results}

\section{Selection of participants}

Of the initial 6733 participants, 2546 (37.8\%) reported information on birth weight and were thus included in the study. The characteristics of the included and excluded participants are summarized in Additional file 1: Table S1.

\section{Sample's characteristics}

Clinical characteristics according to gender are summarized in Table 1. Age was similar between women and men. Women reported lower tobacco consumption, had a lower BMI and higher body fat levels and were less frequently overweight and obese than men. Women also reported lower birth weights and had higher leptin and adiponectin levels than men. Of the 2546 participants included in the analysis, 2404 (94.4\%) were considered as Caucasian.

\section{Birth weight and obesity markers}

Bivariate associations between anthropometric markers and birth weight group are summarized in Table 2 (for women) and Table 3 (for men). All anthropometric
Table 1 Clinical characteristics of participants, by gender

\begin{tabular}{|c|c|c|c|}
\hline & Women $(n=1458)$ & Men $(n=1088)$ & $p$ value \\
\hline Age (years) & $50.2 \pm 10.1$ & $49.7 \pm 9.9$ & 0.197 \\
\hline BMI $\left(\mathrm{kg} / \mathrm{m}^{2}\right)$ & $24.5 \pm 4.8$ & $26.4 \pm 3.9$ & $<0.001$ \\
\hline BMI categories (\%) & & & $<0.001$ \\
\hline Normal & $907(62.2)$ & $429(39.4)$ & \\
\hline Overweight & $375(25.7)$ & $491(45.1)$ & \\
\hline Obese & $176(12.1)$ & $168(15.4)$ & \\
\hline $\begin{array}{l}\text { Waist circumference } \\
(\mathrm{cm})\end{array}$ & $82.0 \pm 12.4$ & $95.0 \pm 11.2$ & $<0.001$ \\
\hline Abdominal obesity (\%) & $409(28.1)$ & $269(24.8)$ & 0.062 \\
\hline Body fat (\%) & $33.0 \pm 8.0$ & $22.9 \pm 6.0$ & $<0.001$ \\
\hline Physically active (\%) & $855(58.6)$ & $611(56.2)$ & 0.210 \\
\hline Menopausal status (\%) & $632(43.4)$ & NR & \\
\hline Smoking status & & & $<0.001$ \\
\hline Never & $694(47.6)$ & $385(35.4)$ & \\
\hline Former & $384(26.3)$ & $384(35.3)$ & \\
\hline Current & $380(26.1)$ & $319(29.3)$ & \\
\hline Birth weight (kg) & $3.3 \pm 1.0$ & $3.5 \pm 0.7$ & $<0.001$ \\
\hline $\begin{array}{l}\text { Birth weight } \\
\text { categories (\%) }\end{array}$ & & & $<0.001$ \\
\hline$\leq 2.5 \mathrm{~kg}$ & $174(11.9)$ & $73(6.7)$ & \\
\hline $2.6-3.5 \mathrm{~kg}$ & $891(61.1)$ & $556(51.1)$ & \\
\hline $3.6-4.0 \mathrm{~kg}$ & $264(18.1)$ & $266(24.5)$ & \\
\hline$>4.0 \mathrm{~kg}$ & $129(8.9)$ & $193(17.7)$ & \\
\hline
\end{tabular}

Results are expressed as mean \pm standard deviation or number of people and (percentage). Normal weight was defined as a body mass index (BMI) $<25 \mathrm{~kg} /$ $\mathrm{m}^{2}$; abdominal obesity was defined as a waist circumference $\geq 88 \mathrm{~cm}$ for women and $\geq 102 \mathrm{~cm}$ in men. Between-gender comparisons performed using Student's t test or Chi square

NR not relevant

markers showed significant differences between birth weight categories in both genders, with the exception of total fat mass in men (Table 3). Conversely, leptin levels did not differ between birth weight categories.

The results of the multivariate analysis of the associations between anthropometric markers and birth weight categories are summarized in Table 4 (for women) and Table 5 (for men). The inverse associations between birth weight and height or weight persisted in both genders. In women, both low and high birth weights were associated with a lower likelihood of presenting with normal weight in adulthood, while birth weights $>3.5 \mathrm{~kg}$ were associated with a higher likelihood of developing abdominal obesity (Table 4). In men, a similar but nonsignificant inverse association was found between low birth weight and likelihood of presenting with normal weight in adulthood, and similar associations between birth weights $>3.5 \mathrm{~kg}$ and normal weight or abdominal obesity were found (Table 5). A significant inverse association was also found between reported birth weight and the leptin to fat 
Table 2 Distribution of anthropometric and biological variables according to birth weight, women, unadjusted

\begin{tabular}{|c|c|c|c|c|c|}
\hline & \multicolumn{4}{|c|}{ Birth weight categories (kg) } & \multirow[t]{2}{*}{$p$ value } \\
\hline & $-2.5](n=174)$ & ]2.5-3.5] $(n=891)$ & ]3.5-4.0] $(n=264)$ & $14.0+(n=129)$ & \\
\hline \multicolumn{6}{|l|}{ Anthropometry } \\
\hline Height $(\mathrm{cm})$ & $161 \pm 1^{\mathrm{a}}$ & $164 \pm 1^{b}$ & $165 \pm 1^{c}$ & $166 \pm 1^{c}$ & $<0.001$ \\
\hline Weight (kg) & $64.7 \pm 1.0^{\mathrm{a}}$ & $64.6 \pm 0.4^{\mathrm{a}}$ & $69.2 \pm 0.8^{b}$ & $69.9 \pm 1.1^{b}$ & $<0.001$ \\
\hline $\mathrm{BMI}\left(\mathrm{kg} / \mathrm{m}^{2}\right)$ & $25.0 \pm 0.4^{a, b}$ & $24.1 \pm 0.2^{\mathrm{a}}$ & $25.4 \pm 0.3^{b}$ & $25.5 \pm 0.4^{b}$ & $<0.001$ \\
\hline Waist circumference (cm) & $83.7 \pm 0.9^{a, b}$ & $80.8 \pm 0.4^{\mathrm{a}}$ & $83.4 \pm 0.8^{b}$ & $84.6 \pm 1.1^{b}$ & $<0.001$ \\
\hline Fat (\% of body weight) & $34.4 \pm 0.6^{\mathrm{a}}$ & $32.3 \pm 0.3^{b}$ & $33.5 \pm 0.5^{a, b}$ & $34.1 \pm 0.7^{a, b}$ & 0.002 \\
\hline Fat mass (kg) & $22.9 \pm 0.7^{\mathrm{a}, \mathrm{b}}$ & $21.4 \pm 0.3^{\mathrm{a}}$ & $24.1 \pm 0.6^{b}$ & $24.4 \pm 0.8^{b}$ & $<0.001$ \\
\hline BMl categories (\%) & & & & & $<0.001$ \\
\hline Normal & $98(56.3)$ & $592(66.4)$ & $150(56.8)$ & $67(51.9)$ & \\
\hline Overweight & $48(27.6)$ & $220(24.7)$ & $68(25.8)$ & $39(30.2)$ & \\
\hline Obesity & $28(16.1)$ & $79(8.9)$ & $46(17.4)$ & $23(17.8)$ & \\
\hline Abdominal obesity (\%) & $57(32.8)$ & $220(24.7)$ & $83(31.4)$ & $49(38.0)$ & 0.002 \\
\hline \multicolumn{6}{|l|}{ Adipokines } \\
\hline Leptin (ng/dL) & $18.1 \pm 0.9$ & $15.4 \pm 0.4$ & $16.9 \pm 0.7$ & $15.9 \pm 1.1$ & $0.230^{\S}$ \\
\hline Leptin/fat mass ratio & $0.77 \pm 0.04^{\mathrm{a}}$ & $0.72 \pm 0.02^{a, b}$ & $0.71 \pm 0.03^{a, b}$ & $0.61 \pm 0.04^{b}$ & 0.035 \\
\hline Adiponectin $(\mu \mathrm{g} / \mathrm{dL})$ & $11.8 \pm 0.7$ & $12.2 \pm 0.3$ & $11.9 \pm 0.5$ & $12.5 \pm 0.8$ & $0.612^{\S}$ \\
\hline \multicolumn{6}{|c|}{ Markers of glucose homeostasis } \\
\hline Fasting glucose (mmol/L) & $5.46 \pm 0.06^{\mathrm{a}}$ & $5.24 \pm 0.03^{b}$ & $5.28 \pm 0.05^{a, b}$ & $5.30 \pm 0.07^{a, b}$ & 0.013 \\
\hline Fasting insulin $(\mu \mathrm{U} / \mathrm{mL})$ & $8.5 \pm 0.4$ & $7.3 \pm 0.2$ & $8.4 \pm 0.3$ & $6.9 \pm 0.5$ & 0.003 \\
\hline HOMA & $2.10 \pm 0.12$ & $1.76 \pm 0.05$ & $2.05 \pm 0.10$ & $1.68 \pm 0.14$ & 0.004 \\
\hline Diabetes (\%) & $11(6.3)$ & $17(1.9)$ & $7(2.7)$ & $6(4.7)$ & 0.007 \\
\hline High HOMA (\%) & $35(24.3)$ & $117(16.5)$ & $37(18.5)$ & $15(15.2)$ & 0.133 \\
\hline Metabolic syndrome (\%) & $39(22.4)$ & $113(12.7)$ & $37(14.0)$ & $21(16.3)$ & 0.009 \\
\hline
\end{tabular}

Results are expressed as number of people and (column percentage), as average \pm standard deviation. Normal weight was defined as a body mass index $<25 \mathrm{~kg} /$ $\mathrm{m}^{2}$; abdominal obesity was defined as a waist circumference $\geq 88 \mathrm{~cm}$ for women and $\geq 102 \mathrm{~cm}$ in men. Between-group comparisons performed using Chi square for categorical variables and by ANOVA for continuous variables. For continuous variables, post hoc pairwise comparisons using the method of Scheffe were performed when the results of the ANOVA were statistically significant; results with a different subscript are significantly different at $\mathrm{p}<0.05$ (corrected for multiple comparisons). For fasting insulin and HOMA, no pairwise difference at $\mathrm{p}<0.05$ (corrected for multiple comparisons) was found

$\S$ Statistical analysis performed on log-transformed data

mass ratio in both women and men, while no differences in adiponectin levels were found between birth weight groups (Tables 4, 5). Sensitivity analysis restricting to people reporting a birth weight $>1.5 \mathrm{~kg}$ led to similar findings (Additional file 1: Tables S2a, S2b).

\section{Birth weight and markers of glucose homeostasis}

Bivariate associations between markers of glucose homeostasis and birth weight group are summarized in Table 2 (for women) and Table 3 (for men). Fasting glucose, insulin and HOMA levels and prevalence of diabetes and metabolic syndrome showed significant differences between birth weight categories in women (Table 2) but not in men (Table 3).

The results of the multivariate analysis of the associations between markers of glucose homeostasis and birth weight categories are summarized in Table 4 (for women) and Table 5 (for men). In women, low birth weight was associated with a higher likelihood of developing diabetes, insulin resistance (as assessed by high HOMA levels) and metabolic syndrome (Table 4). Conversely, no significant associations were found in men, with the exception that birth weights $>4.0 \mathrm{~kg}$ were associated with a higher likelihood of developing metabolic syndrome (Table 5). Sensitivity analysis restricting to people reporting a birth weight $>1.5 \mathrm{~kg}$ led to similar findings, low birth weight being now also significantly associated with diabetes in men (Additional file 1: Table S2a, b).

\section{Discussion}

To our knowledge, this is the largest population-based study to assess the associations between birth weight and adult levels of markers of glucose homeostasis, obesity, leptin and adiponectin in Europe. Our findings provide some insight regarding the differential effects of low and high birth weight on diabetes and obesity markers in later life. 
Table 3 Distribution of anthropometric and biological variables according to birth weight, men, unadjusted

\begin{tabular}{|c|c|c|c|c|c|}
\hline & \multicolumn{4}{|c|}{ Birth weight categories (kg) } & \multirow[t]{2}{*}{$p$ value } \\
\hline & $-2.5](n=73)$ & ]2.5-3.5] $(n=556)$ & ]3.5-4.0] $(n=266)$ & $14.0+(n=193)$ & \\
\hline \multicolumn{6}{|l|}{ Anthropometry } \\
\hline Height (cm) & $175 \pm 1^{\mathrm{a}, \mathrm{c}}$ & $175 \pm 1^{\mathrm{a}}$ & $178 \pm 1^{b, c}$ & $179 \pm 1^{b}$ & $<0.001$ \\
\hline Weight (kg) & $80.8 \pm 1.5^{a, c}$ & $80.0 \pm 0.6^{\mathrm{a}}$ & $84.5 \pm 0.8^{b, c}$ & $87.0 \pm 0.9^{b}$ & $<0.001$ \\
\hline $\mathrm{BMI}\left(\mathrm{kg} / \mathrm{m}^{2}\right)$ & $26.3 \pm 0.5^{\mathrm{a}}$ & $26.0 \pm 0.2^{\mathrm{a}}$ & $26.8 \pm 0.2^{b}$ & $27.2 \pm 0.3^{b}$ & $<0.001$ \\
\hline Waist circumference $(\mathrm{cm})$ & $94.8 \pm 1.3^{a, b}$ & $93.8 \pm 0.5^{b}$ & $95.9 \pm 0.7^{a, b}$ & $97.4 \pm 0.8^{\mathrm{a}}$ & $<0.001$ \\
\hline Fat (\% of body weight) & $23.5 \pm 0.7$ & $22.5 \pm 0.3$ & $23.2 \pm 0.4$ & $23.6 \pm 0.4$ & 0.089 \\
\hline Fat mass (kg) & $19.3 \pm 0.9^{a, b}$ & $18.4 \pm 0.3^{b}$ & $20.1 \pm 0.5^{a, b}$ & $21.0 \pm 0.5^{\mathrm{a}}$ & $<0.001$ \\
\hline BMl categories (\%) & & & & & 0.004 \\
\hline Normal & $28(38.4)$ & $248(44.6)$ & $99(37.2)$ & $54(28.0)$ & \\
\hline Overweight & $33(45.2)$ & $236(42.5)$ & $120(45.1)$ & $102(52.9)$ & \\
\hline Obesity & $12(16.4)$ & $72(13.0)$ & $47(17.7)$ & $37(19.2)$ & \\
\hline Abdominal obesity (\%) & $15(20.6)$ & $124(22.3)$ & $68(25.6)$ & $62(32.1)$ & 0.043 \\
\hline \multicolumn{6}{|l|}{ Adipokines } \\
\hline Leptin (ng/dL) & $10.0 \pm 1.0$ & $8.6 \pm 0.4$ & $8.2 \pm 0.5$ & $8.7 \pm 0.6$ & $0.635^{\S}$ \\
\hline Leptin/fat mass ratio & $0.46 \pm 0.05$ & $0.45 \pm 0.02$ & $0.39 \pm 0.02$ & $0.38 \pm 0.03$ & 0.097 \\
\hline Adiponectin $(\mu \mathrm{g} / \mathrm{dL})$ & $8.1 \pm 0.7$ & $7.2 \pm 0.2$ & $7.1 \pm 0.4$ & $7.3 \pm 0.4$ & $0.848^{\S}$ \\
\hline \multicolumn{6}{|c|}{ Markers of glucose homeostasis } \\
\hline Fasting glucose (mmol/L) & $5.80 \pm 0.14$ & $5.64 \pm 0.05$ & $5.67 \pm 0.07$ & $5.60 \pm 0.08$ & 0.655 \\
\hline Fasting insulin $(\mu \mathrm{U} / \mathrm{mL})$ & $10.0 \pm 0.9$ & $9.5 \pm 0.3$ & $9.0 \pm 0.5$ & $9.5 \pm 0.5$ & 0.745 \\
\hline HOMA & $2.79 \pm 0.3$ & $2.45 \pm 0.11$ & $2.42 \pm 0.15$ & $2.50 \pm 0.18$ & 0.712 \\
\hline Diabetes (\%) & $9(12.3)$ & $33(5.9)$ & $17(6.4)$ & $11(5.7)$ & 0.202 \\
\hline High HOMA (\%) & $18(29.5)$ & $139(29.8)$ & $63(27.9)$ & $46(27.7)$ & 0.938 \\
\hline Metabolic syndrome (\%) & $17(23.3)$ & $134(24.1)$ & $64(24.1)$ & $61(31.6)$ & 0.183 \\
\hline
\end{tabular}

Results are expressed as number of people and (column percentage) or as average \pm standard deviation. Normal weight was defined as a body mass index $<25 \mathrm{~kg} /$ $\mathrm{m}^{2}$; abdominal obesity was defined as a waist circumference $\geq 88 \mathrm{~cm}$ for women and $\geq 102 \mathrm{~cm}$ in men. Statistical analysis by Chi square for categorical variables and by ANOVA for continuous variables. For continuous variables, post hoc pairwise comparisons using the method of Scheffe were performed when the results of the ANOVA were statistically significant; results with a different subscript are significantly different at $\mathrm{p}<0.05$ (corrected for multiple comparisons)

$\S$ Statistical analysis performed on log-transformed data

Here, we report higher levels in markers of glucose homeostasis in people reporting low birth weight, but also a U-shaped association between birth weight and most obesity markers, notably among women. Those findings are in agreement with the literature $[1,16,17]$, and indicate that low birth weight is associated with increased risk of diabetes and obesity in later life.

\section{Birth weight and obesity markers}

Leptin is a hormone produced by the adipose tissue and is classically increased in type 2 diabetes [18], but is mostly associated with obesity [19]. Diet early in life might regulate leptin levels [15], which in turn will influence energy intake and risk of obesity [4]. In this study, adult leptin levels decreased consistently with increased birth weight in both genders; those findings are in agreement with some studies $[4,5]$ but not with other smaller sized studies, none of which being population-based (Jaquet et al. (case-control study, $\mathrm{N}=26$ cases and 25 controls, age $=24$ years) [20]; Melo et al. $\mathrm{N}=165$, not population-based, only women) [21]). Similarly, the leptin to fat mass ratio significantly decreased with increasing birth weight in both gender, a finding that, to our knowledge, had not been reported previously. Overall, the decrease in leptin levels and in the leptin to fat mass ratio with birth weight suggest that the mechanisms by which low or high birth weight influence the development of obesity in later life might be different. Interestingly, it has been suggested that children born with a low weight develop high leptin levels during catch-up growth, which suggests leptin resistance [22]. Hence, our data suggest that the high leptin levels observed at birth and during childhood for low birth children could actually be maintained in later life. Another possible mechanism would be adipocyte dysfunction: catch-up growth is associated with adipocyte hypertrophy in male rats [23], hypertrophic adipocytes or adipocytes from low birth weight animals have a distinct gene expression [24] and high leptin levels are more closely associated with adipose cell hypertrophy than with adipose 
Table 4 Distribution of anthropometric and biological variables according to birth weight, women, multivariate adjusted

\begin{tabular}{|c|c|c|c|c|c|c|c|}
\hline & \multicolumn{4}{|c|}{ Birth weight categories (kg) } & \multirow[t]{2}{*}{$p$ value } & \multirow[t]{2}{*}{ Linear } & \multirow[t]{2}{*}{ Quadrati } \\
\hline & $-2.5](n=174)$ & ]2.5-3.5] $(n=891)$ & ]3.5-4.0] $(n=264)$ & $14.0+(n=129)$ & & & \\
\hline \multicolumn{8}{|l|}{ Anthropometry ${ }^{\text {a }}$} \\
\hline Height (cm) & $161 \pm 1$ & $164 \pm 1$ & $165 \pm 1$ & $166 \pm 1$ & $<0.001$ & $<0.001$ & 0.069 \\
\hline Weight (kg) & $64.5 \pm 1$ & $64.7 \pm 0.4$ & $69.2 \pm 0.8$ & $69.8 \pm 1.1$ & $<0.001$ & $<0.001$ & 0.797 \\
\hline $\mathrm{BMI}\left(\mathrm{kg} / \mathrm{m}^{2}\right)$ & $24.8 \pm 0.4$ & $24.1 \pm 0.2$ & $25.4 \pm 0.3$ & $25.4 \pm 0.4$ & $<0.001$ & 0.086 & 0.285 \\
\hline Waist circumference (cm) & $83.1 \pm 0.9$ & $81.0 .0 \pm 0.4$ & $83.5 \pm 0.7$ & $83.9 \pm 1.1$ & 0.002 & 0.259 & 0.125 \\
\hline Fat (\% of body weight) & $33.8 \pm 0.6$ & $32.5 \pm 0.2$ & $33.6 \pm 0.5$ & $33.2 \pm 0.6$ & 0.061 & 0.861 & 0.421 \\
\hline Fat mass (kg) & $22.4 \pm 0.7$ & $21.6 \pm 0.3$ & $24.1 \pm 0.6$ & $23.8 \pm 0.8$ & $<0.001$ & 0.033 & 0.692 \\
\hline Normal weight & $0.70(0.50-0.98)$ & 1 (ref.) & $0.66(0.50-0.88)$ & $0.59(0.40-0.86)$ & & 0.197 & 0.089 \\
\hline Abdominal obesity & $1.35(0.94-1.94)$ & 1 (ref.) & $1.40(1.03-1.90)$ & $1.67(1.12-2.49)$ & - & 0.206 & 0.106 \\
\hline \multicolumn{8}{|l|}{ Adipokines } \\
\hline Leptin (ng/dL) $)^{a}$ & $17.8 \pm 0.9$ & $15.5 \pm 0.4$ & $16.9 \pm 0.7$ & $16.0 \pm 1.1$ & $0.357^{\S}$ & $0.337^{\S}$ & $0.522^{\S}$ \\
\hline Leptin $(\mathrm{ng} / \mathrm{dL})^{\mathrm{b}}$ & $16.9 \pm 0.6$ & $16.3 \pm 0.3$ & $15.8 \pm 0.5$ & $13.8 \pm 0.8$ & $0.008^{\S}$ & $0.004^{\S}$ & $0.241^{\S}$ \\
\hline Leptin $(\mathrm{ng} / \mathrm{dL})^{c}$ & $16.7 \pm 0.7$ & $16.1 \pm 0.3$ & $16.1 \pm 0.6$ & $14.4 \pm 0.8$ & $0.147^{\S}$ & $0.050^{\S}$ & $0.341^{\S}$ \\
\hline Leptin $(\mathrm{ng} / \mathrm{dL})^{\mathrm{d}}$ & $17.3 \pm 0.7$ & $16.2 \pm 0.3$ & $15.6 \pm 0.5$ & $14.0 \pm 0.8$ & $0.012^{\S}$ & $0.003^{\S}$ & $0.541^{\S}$ \\
\hline Leptin/fat mass ratio ${ }^{b}$ & $0.77 \pm 0.04$ & $0.73 \pm 0.02$ & $0.69 \pm 0.03$ & $0.62 \pm 0.04$ & 0.029 & 0.004 & 0.655 \\
\hline Adiponectin $(\mu \mathrm{g} / \mathrm{dL})^{\mathrm{a}}$ & $11.6 \pm 0.7$ & $12.3 \pm 0.3$ & $11.9 \pm 0.5$ & $12.2 \pm 0.8$ & $0.560^{\S}$ & 0.244 & 0.867 \\
\hline Adiponectin $(\mu \mathrm{g} / \mathrm{dL})^{\mathrm{b}}$ & $11.8 \pm 0.7$ & $12.1 \pm 0.3$ & $12.2 \pm 0.5$ & $12.5 \pm 0.8$ & $0.433^{\S}$ & $0.105^{\S}$ & $0.796^{\S}$ \\
\hline Adiponectin $(\mu \mathrm{g} / \mathrm{dL})^{c}$ & $11.9 \pm 0.7$ & $12.1 \pm 0.3$ & $12.2 \pm 0.5$ & $12.5 \pm 0.8$ & $0.594^{\S}$ & $0.150^{\S}$ & $0.800^{\S}$ \\
\hline Adiponectin $(\mu \mathrm{g} / \mathrm{dL})^{d}$ & $11.7 \pm 0.6$ & $12.1 \pm 0.3$ & $12.2 \pm 0.5$ & $12.5 \pm 0.8$ & $0.406^{\S}$ & $0.090^{\S}$ & $0.970^{\S}$ \\
\hline \multicolumn{8}{|l|}{ Markers of glucose homeostasis } \\
\hline Fasting Glucose $(\mathrm{mmol} / \mathrm{L})^{\mathrm{b}, \mathrm{e}}$ & $5.37 \pm 0.05$ & $5.28 \pm 0.02$ & $5.26 \pm 0.04$ & $5.18 \pm 0.06$ & 0.115 & 0.016 & 0.903 \\
\hline Fasting Insulin $(\mu \mathrm{U} / \mathrm{mL})^{\mathrm{b}, \mathrm{e}}$ & $8.2 \pm 0.4$ & $7.5 \pm 0.2$ & $8.0 \pm 0.3$ & $6.5 \pm 0.4$ & 0.012 & 0.008 & 0.194 \\
\hline$H O M A^{b, e}$ & $1.99 \pm 0.1$ & $1.83 \pm 0.04$ & $1.95 \pm 0.08$ & $1.50 \pm 0.12$ & 0.006 & 0.004 & 0.106 \\
\hline Diabetes $^{\mathrm{b}}$ & $2.43(1.02-5.79)$ & 1 (ref.) & $0.75(0.27-2.12)$ & $1.40(0.50-3.98)$ & - & 0.285 & 0.053 \\
\hline Diabetes $^{c}$ & $2.38(0.97-5.84)$ & 1 (ref.) & $0.89(0.32-2.48)$ & $1.86(0.65-5.29)$ & - & 0.634 & 0.042 \\
\hline Diabetes $^{d}$ & $2.70(1.13-6.45)$ & 1 (ref.) & $0.71(0.25-2.03)$ & $1.17(0.38-3.55)$ & - & 0.134 & 0.067 \\
\hline High $\mathrm{HOMA}^{\mathrm{b}}$ & $1.32(0.83-2.12)$ & 1 (ref.) & $0.81(0.51-1.28)$ & $0.63(0.33-1.19)$ & - & 0.031 & 0.947 \\
\hline Metabolic syndrome $e^{a}$ & $1.75(1.15-2.68)$ & 1 (ref.) & $1.12(0.74-1.69)$ & $1.05(0.62-1.79)$ & - & 0.140 & 0.195 \\
\hline
\end{tabular}

Results are expressed as adjusted mean \pm standard error or as odds ratio and ( $95 \%$ confidence interval). Normal weight was defined as a body mass index $<25 \mathrm{~kg} /$ $\mathrm{m}^{2}$; abdominal obesity was defined as a waist circumference $\geq 88 \mathrm{~cm}$ for women and $\geq 102 \mathrm{~cm}$ in men. Statistical analysis conducted using analysis of variance for continuous variables and logistic regression for categorical variables. Statistically significant odds ratios are indicated in italics. Column $p$ value corresponds to the $p$ value of the overall association test; column linear trend corresponds to the $p$ value for testing a linear trend. Adjusted for: ${ }^{a}$ age, smoking status and physical activity; ${ }^{\mathrm{b}}$ age, smoking status, physical activity and BMl; ${ }^{\mathrm{c}}$ age, smoking status, physical activity and waist circumference; ${ }^{\mathrm{d}}$ age, smoking status, physical activity and fat mass. Also adjusted for ${ }^{\mathrm{e}}$ antidiabetic drug treatment

$\S$ Statistical analysis performed on log-transformed data

tissue hyperplasia [25]. Nevertheless, these findings in animals are not corroborated in cultured preadipocytes isolated from adult people born with low birth weight. Indeed, these preadipocytes show reduced leptin expression and release compared to people born with a normal weight, suggesting impaired preadipocytes maturation [26]. These surprising results might be due to the fact that adult body weight was significantly lower in people born with a low weight compared to people born with a normal weight. Moreover, fat mass assessed by DEXA was similar between groups and this study was only performed in males [26]. Finally, the high leptin to fat mass ratio observed in people born with a low weight could be a sequel of malnutrition during foetal life [27]. Overall, our data suggest that low birth weight leads to increased adult leptin levels due to the association of leptin resistance and increased leptin production as assessed by the leptin to fat mass ratio.

High birth weight has also been shown to be related with obesity $[28,29]$, although other studies suggest that high birth weight is actually more related to lean than to fat mass (for a review, see [30]). Still, no differences in body fat percentage and fat mass were found between low and high birth weight groups in both genders, even when the analysis was restricted to obese people (not shown). Hence, the hypothesis that a high birth weight is related 
Table 5 Distribution of anthropometric and biological variables according to birth weight, men, multivariate adjusted

\begin{tabular}{|c|c|c|c|c|c|c|c|}
\hline & \multicolumn{4}{|c|}{ Birth weight categories (kg) } & \multirow[t]{2}{*}{ p value } & \multirow[t]{2}{*}{ Linear } & \multirow[t]{2}{*}{ Quadratic } \\
\hline & $-2.5](n=73)$ & ]2.5-3.5] $(n=556)$ & ]3.5-4.0] $(n=266)$ & ] $4.0+(n=193)$ & & & \\
\hline \multicolumn{8}{|l|}{ Anthropometry ${ }^{\text {a }}$} \\
\hline Height (cm) & $175 \pm 1$ & $176 \pm 1$ & $178 \pm 1$ & $179 \pm 1$ & $<0.001$ & $<0.001$ & 0.306 \\
\hline Weight (kg) & $80.6 \pm 1.5$ & $80.0 \pm 0.5$ & $84.6 \pm 0.8$ & $86.9 \pm 0.9$ & $<0.001$ & $<0.001$ & 0.147 \\
\hline BMI $\left(\mathrm{kg} / \mathrm{m}^{2}\right)$ & $26.2 \pm 0.4$ & $26.0 \pm 0.2$ & $26.8 \pm 0.2$ & $27.1 \pm 0.3$ & $<0.001$ & 0.024 & 0.328 \\
\hline Waist circumference (cm) & $94.8 \pm 1.2$ & $93.7 \pm 0.4$ & $96.1 \pm 0.6$ & $97.3 \pm 0.8$ & $<0.001$ & 0.022 & 0.168 \\
\hline Fat (\% of body weight) & $23.7 \pm 0.6$ & $22.4 \pm 0.2$ & $23.3 \pm 0.3$ & $23.4 \pm 0.4$ & 0.018 & 0.946 & 0.075 \\
\hline Fat mass (kg) & $19.4 \pm 0.8$ & $18.3 \pm 0.3$ & $20.2 \pm 0.4$ & $20.9 \pm 0.5$ & $<0.001$ & 0.035 & 0.117 \\
\hline Normal weight & $0.75(0.45-1.26)$ & 1 (ref.) & $0.71(0.52-0.96)$ & $0.47(0.33-0.68)$ & - & 0.055 & 0.043 \\
\hline Abdominal obesity & $0.90(0.48-1.70)$ & 1 (ref.) & $1.27(0.89-1.82)$ & $1.72(1.17-2.53)$ & - & 0.039 & 0.610 \\
\hline \multicolumn{8}{|l|}{ Adipokines } \\
\hline Leptin $(\mathrm{ng} / \mathrm{dL})^{\mathrm{a}}$ & $10.0 \pm 1.0$ & $8.6 \pm 0.3$ & $8.2 \pm 0.5$ & $8.7 \pm 0.6$ & $0.649^{\S}$ & $0.544^{\S}$ & $0.209^{\S}$ \\
\hline Leptin $(\mathrm{ng} / \mathrm{dL})^{\mathrm{b}}$ & $10.1 \pm 0.8$ & $9.0 \pm 0.3$ & $8.0 \pm 0.4$ & $7.9 \pm 0.5$ & $0.088^{\S}$ & $0.039^{\S}$ & $0.534^{\S}$ \\
\hline Leptin $(\mathrm{ng} / \mathrm{dL})^{c}$ & $10.1 \pm 0.8$ & $9.0 \pm 0.3$ & $8.0 \pm 0.4$ & $7.8 \pm 0.5$ & $0.055^{\S}$ & $0.031^{\S}$ & $0.721^{\S}$ \\
\hline Leptin $(\mathrm{ng} / \mathrm{dL})^{\mathrm{d}}$ & $9.8 \pm 0.8$ & $9.1 \pm 0.3$ & $7.8 \pm 0.4$ & $7.7 \pm 0.5$ & $0.016^{\S}$ & $0.020^{\S}$ & $0.625^{\S}$ \\
\hline Leptin/fat mass ratiob & $0.46 \pm 0.05$ & $0.45 \pm 0.02$ & $0.39 \pm 0.02$ & $0.38 \pm 0.03$ & 0.041 & 0.078 & 0.942 \\
\hline Adiponectin $(\mu \mathrm{g} / \mathrm{dL})^{\mathrm{a}}$ & $8.1 \pm 0.7$ & $7.2 \pm 0.2$ & $7.1 \pm 0.4$ & $7.3 \pm 0.4$ & $0.875^{\S}$ & $0.875^{\S}$ & $0.745^{\S}$ \\
\hline Adiponectin $(\mu \mathrm{g} / \mathrm{dL})^{\mathrm{b}}$ & $8.1 \pm 0.7$ & $7.1 \pm 0.2$ & $7.1 \pm 0.4$ & $7.4 \pm 0.4$ & $0.906^{\S}$ & $0.827^{\S}$ & $0.639^{\S}$ \\
\hline Adiponectin $(\mu \mathrm{g} / \mathrm{dL})^{c}$ & $8.1 \pm 0.7$ & $7.1 \pm 0.2$ & $7.1 \pm 0.4$ & $7.5 \pm 0.4$ & $0.880^{\S}$ & $0.820^{\S}$ & $0.592^{\S}$ \\
\hline Adiponectin $(\mu \mathrm{g} / \mathrm{dL})^{d}$ & $8.1 \pm 0.7$ & $7.1 \pm 0.2$ & $7.2 \pm 0.4$ & $7.4 \pm 0.4$ & $0.898^{\S}$ & $0.838^{\S}$ & $0.577^{\S}$ \\
\hline \multicolumn{8}{|l|}{ Markers of glucose homeostasis } \\
\hline Fasting Glucose $(\mathrm{mmol} / \mathrm{L})^{\mathrm{b}, \mathrm{e}}$ & $5.64 \pm 0.11$ & $5.65 \pm 0.04$ & $5.68 \pm 0.06$ & $5.62 \pm 0.07$ & 0.927 & 0.930 & 0.673 \\
\hline Fasting Insulin $(\mu \mathrm{U} / \mathrm{mL})^{\mathrm{b}, \mathrm{e}}$ & $9.5 \pm 0.8$ & $9.8 \pm 0.3$ & $8.8 \pm 0.4$ & $9.1 \pm 0.5$ & 0.199 & 0.434 & 0.894 \\
\hline $\mathrm{HOMA}^{\mathrm{b}, \mathrm{e}}$ & $2.50 \pm 0.25$ & $2.55 \pm 0.09$ & $2.36 \pm 0.13$ & $2.39 \pm 0.15$ & 0.634 & 0.571 & 0.946 \\
\hline Diabetes $^{b}$ & $2.31(0.96-5.60)$ & 1 (ref.) & $0.86(0.44-1.68)$ & $0.75(0.36-1.59)$ & - & 0.029 & 0.257 \\
\hline Diabetes ${ }^{c}$ & $2.23(0.92-5.41)$ & 1 (ref.) & $0.88(0.45-1.72)$ & $0.72(0.34-1.52)$ & - & 0.030 & 0.337 \\
\hline Diabetes $^{d}$ & $2.19(0.90-5.33)$ & 1 (ref.) & $0.87(0.44-1.71)$ & $0.71(0.33-1.53)$ & - & 0.032 & 0.352 \\
\hline High HOMA ${ }^{b}$ & $0.84(0.44-1.60)$ & 1 (ref.) & $0.77(0.52-1.13)$ & $0.67(0.44-1.03)$ & - & 0.407 & 0.451 \\
\hline Metabolic syndrome $e^{a}$ & $0.96(0.52-1.76)$ & 1 (ref.) & $1.05(0.73-1.50)$ & $1.49(1.02-2.17)$ & - & 0.185 & 0.410 \\
\hline
\end{tabular}

Results are expressed as adjusted mean \pm standard error or as odds ratio and ( $95 \%$ confidence interval). Normal weight was defined as a body mass index $<25 \mathrm{~kg} /$ $\mathrm{m}^{2}$; abdominal obesity was defined as a waist circumference $\geq 88 \mathrm{~cm}$ for women and $\geq 102 \mathrm{~cm}$ in men. Statistical analysis conducted using analysis of variance for continuous variables and logistic regression for categorical variables. Statistically significant odds ratios are indicated in italics. Column $p$ value corresponds to the $p$ value of the overall association test; column linear trend corresponds to the $p$ value for testing a linear trend. Adjusted for: ${ }^{a}$ age, smoking status and physical activity; ${ }^{b}$ age, smoking status, physical activity and BMl; ${ }^{C}$ age, smoking status, physical activity and waist circumference; ${ }^{d}$ age, smoking status, physical activity and fat mass. Also adjusted for ${ }^{e}$ antidiabetic drug treatment

$\S$ Statistical analysis performed on log-transformed data

to an increased lean mass in later life is not confirmed by our data. Again, the precise mechanisms for the increased obesity risk among high birth weight children remain to be assessed. Maternal obesity is the most likely explanation, as it is related to foetal macrosomia and to increased risk of obesity [31, 32], although this statement has been challenged [33]. Indeed, the socio-economic position of the mother might be the strongest determinant, as it is associated with a number of risk factors for child obesity [34]. Conversely, the reasons for lower leptin and leptin to fat mass ratio in people born with a high weight can only be speculated. Increased birth weight is associated with high leptin levels $[35,36]$, which can be further reduced by breastfeeding [15]. The fact that participants with a high birth weight also present with the lowest leptin levels could thus be due to differences in nutrition in early life, or in adipocyte metabolism [24-26] as assessed by a lower leptin production by body fat unit. Still, further studies are needed to explain those findings.

Adiponectin is another protein secreted by adipocytes. Reduced levels of adiponectin are observed in obese people [37] and associated with an increased risk of type 2 diabetes [8]. Blood cord adiponectin levels are positively related with birth weight and BMI in newborns [7], although this statement has been challenged [9]. Indeed, a study found lower adiponectin levels in young adults 
born small for gestational age (SGA) [38], while another reported higher adiponectin levels in prepubertal children born SGA compared to children born with low weight adequate for gestational age [39]. In our study, no association was found between birth weight and plasma adiponectin levels, suggesting that adiponectin does not mediate the associations between low or high birth weight and diabetes or obesity risk in middle-aged people, a finding also reported by others [6,39-41]. Further studies are needed to better understand the potential link between adiponectin and birth weight, by notably evaluating the role of catch-up growth in this process.

\section{Birth weight and markers of glucose homeostasis}

The association of markers of glucose homeostasis with low birth weight remained after adjustment for obesity markers, suggesting that low birth weight increases diabetes risk through mechanisms that are independent of obesity or body composition, warranting further research. It has been suggested that people born with a low weight tend to have a more visceral distribution of obesity and significantly reduced muscle mass, with an increased body fat content [42]. A study suggested that low fat deposition leading to thinness at birth and during infancy results in fat acquisition during childhood, with a subsequent increase in the risk of developing type 2 diabetes [43]. Indeed, a higher waist circumference and percentage of body fat were observed in women born with a low weight, but not in men. Moreover, women born with a low weight also presented higher BMI and obesity levels. Hence, although our findings partly confirm that people born with a low weight tend to present a higher body fat content and diabetes risk, further studies are needed to better assess this point, namely regarding the differences between genders. An important confounder could be catch-up growth during the first years of life, as it is more closely linked to adult adiposity than birth weight [44-47].

\section{Possible impact on cardiovascular disease}

Low birth weight has been shown to be significantly associated with increased all-cause mortality in both genders and with increased cardiovascular mortality in men [48]. The higher leptin levels observed among participants born with a low weight might partly contribute to this observation, as higher leptin levels have been shown to be an independent risk factor for cardiovascular disease among diabetic patients $[49,50]$. Low birth weight might also impact vascular endothelium properties [51] and increases the risk of obesity and type 2 diabetes [52], probably via a common genetic mechanism $[53,54]$. Further, earlier age at menarche among obese adolescents might also be an independent risk factor for the development of type 2 diabetes and cardiometabolic disease [55]. Overall, our results suggest that people born with a low weight should be counselled regarding the risks of developing diabetes and/or cardiovascular disease.

\section{Study limitations}

Our study has several limitations. First, the participation rate was low (41\%), which might limit the generalization of the findings; yet, this participation rate is in line with other epidemiological studies [56]. In addition, the distribution of age groups $35-54$ and 55-75 in the CoLaus study was comparable to the source population and there was no gender or zip code distribution difference between the source population and the CoLaus participants (not shown). Second, self-reported birth weight was only available for a subset of participants that substantially differed from participants who did not provide this information. Third, no objective validation of the reported birth weights was performed, thus leading to a possible reporting bias. Still, it has been shown that the validity of self-reported birth weight is high [57]. Fourth, no information regarding gestational age at birth was collected. Hence, it was not possible to distinguish between a low birth weight adequate for gestational age (AGA) from a low birth weight small for gestational age (SGA). This might have confounded our findings, as it has been shown that children born SGA already present with insulin resistance and higher adiponectin levels at prepubertal age, although no difference in leptin levels have been reported [39]. Finally, we could not evaluate the impact of catch-up growth in early life, as we could not record body weight gain during early infancy due to the nature of the CoLaus study.

\section{Conclusion}

Our results suggest that people born with a low weight present a higher prevalence of diabetes and that both low and high birth weight are associated with obesity markers, compared to people born with a normal weight. The higher leptin levels and higher leptin to fat mass ratio among people born with a low weight might be related to nutritional factors during childhood, leptin resistance, or to a higher leptin production by body fat unit.

\section{Additional file}

Additional file 1. Additional tables.

\section{Abbreviations}

ANOVA: analysis of variance; ATP-III: Third Adult Treatment Panel; BF: body fat; BMI: body mass index; CoLaus: cohorte Lausannoise (Lausanne cohort study); CV: coefficient of variation; ELISA: enzyme-linked immunosorbent assay; HOMA: homeostasis model assessment index of insulin resistance. 


\section{Authors' contributions}

PMV and MB made the statistical analysis and wrote part of the article. FRJ, FP, VM, GW and PV contributed to the statistical analysis design, wrote part of the article and made major corrections. All authors read and approved the final manuscript.

\section{Author details}

1 Service of Endocrinology, Diabetes, and Metabolism, Lausanne University Hospital, Lausanne, Switzerland. ${ }^{2}$ Department of Medicine, Department of Internal Medicine, Lausanne University Hospital, Lausanne, Switzerland. ${ }^{3}$ Institute of Social and Preventive Medicine (IUMSP), Lausanne, Switzerland. ${ }^{4}$ Department of Medical Biology, Lausanne University Hospital, Lausanne, Switzerland.

\section{Acknowledgements}

We thank Yolande Barreau, Anne-Lise Bastian, Binasa Ramic, Martine Moranville, Martine Baumer, Marcy Sagette, Jeanne Ecoffey and Sylvie Mermoud for data collection.

\section{Competing interests}

GW and PV received grants from GlaxoSmithKline, the Faculty of Biology and Medicine of Lausanne and the Swiss Science Funding Agency to build the CoLaus study. Murielle Bochud is supported by grants from the Swiss National Foundation for Science (PROSPER: 3200BO-111362/1 and 3233BO-111361/1). François Jornayvaz is supported by a grant from the Fondation Raymond Berger and by the Leenaards Foundation, Lausanne. The other authors report no conflict of interest.

\section{Funding}

The CoLaus study was and is supported by research grants from GlaxoSmithKline, the Faculty of Biology and Medicine of Lausanne, and the Swiss National Science Foundation (Grants 33CSCO-122661, 33CS30-139468 and 33CS30148401). The funding sources had no involvement in study design; in the collection, analysis and interpretation of data; in the writing of the report; and in the decision to submit the article for publication.

Received: 8 March 2016 Accepted: 20 April 2016

Published online: 03 May 2016

\section{References}

1. Barker DJ. The developmental origins of chronic adult disease. Acta Paediatr Suppl. 2004;93(446):26-33.

2. Alberti KG, Zimmet P, Shaw J. Metabolic syndrome-a new world-wide definition. A consensus statement from the international diabetes federation. Diabet Med. 2006;23(5):469-80.

3. Jornayvaz FR, Selz R, Tappy L, Theintz GE. Metabolism of oral glucose in children born small for gestational age: evidence for an impaired whole body glucose oxidation. Metabolism. 2004;53(7):847-51.

4. Lissner L, Karlsson C, Lindroos AK, Sjöström L, Carlsson B, Carlsson L, Bengtsson C. Birth weight, adulthood BMI, and subsequent weight gain in relation to leptin levels in Swedish women. Obes Res. 1999;7(2):150-4.

5. Phillips DI, Fall CH, Cooper C, Norman RJ, Robinson JS, Owens PC. Size at birth and plasma leptin concentrations in adult life. Int J Obes Relat Metab Disord. 1999;23(10):1025-9.

6. Miras M, Ochetti M, Martin S, Silvano L, Sobrero G, Castro L, Onassis M, Tolosa de Talamoni N, Perez A, Picotto G, et al. Serum levels of adiponectin and leptin in children born small for gestational age: relation to insulin sensitivity parameters. J Pediatr Endocrinol Metab. 2010;23(5):463-71.

7. Kotani Y, Yokota I, Kitamura S, Matsuda J, Naito E, Kuroda Y. Plasma adiponectin levels in newborns are higher than those in adults and positively correlated with birth weight. Clin Endocrinol. 2004;61(4):418-23.

8. Ley SH, Harris SB, Connelly PW, Mamakeesick M, Gittelsohn J, Hegele RA, Retnakaran R, Zinman B, Hanley AJ. Adipokines and incident type 2 diabetes in an aboriginal Canadian [corrected] population: the Sandy lake health and diabetes project. Diabetes Care. 2008;31(7):1410-5.

9. Lindsay RS, Walker JD, Havel PJ, Hamilton BA, Calder AA, Johnstone FD. Adiponectin is present in cord blood but is unrelated to birth weight. Diabetes Care. 2003:26(8):2244-9.
10. Firmann M, Mayor V, Marques Vidal P, Bochud M, Pécoud A, Hayoz D, Paccaud F, Preisig M, Song KS, Yuan X, et al. The CoLaus study: a populationbased study to investigate the epidemiology and genetic determinants of cardiovascular risk factors and metabolic syndrome. BMC Cardiovasc Disord. 2008;8(1):6

11. World Health Oranisation. Obesity: preventing and managing the global epidemic: report of a WHO consultation. vol. 894. In: World Health Oranisation editor. Geneva: World Health Organization; 1999. p. 1-268.

12. Ramel A, Geirsdottir OG, Arnarson A, Thorsdottir I. Regional and total body bioelectrical impedance analysis compared with DXA in Icelandic elderly. Eur J Clin Nutr. 2011;65(8):978-83.

13. Matthews DR, Hosker JP, Rudenski AS, Naylor BA, Treacher DF, Turner RC. Homeostasis model assessment: insulin resistance and beta-cell function from fasting plasma glucose and insulin concentrations in man. Diabetologia. 1985;28(7):412-9.

14. Bennett Fl, Farlane-Anderson N, Wilks R, Luke A, Cooper RS, Forrester TE. Leptin concentration in women is influenced by regional distribution of adipose tissue. Am J Clin Nutr. 1997;66(6):1340-4.

15. Singhal A, Farooqi IS, O'Rahilly S, Cole TJ, Fewtrell M, Lucas A. Early nutrition and leptin concentrations in later life. Am J Clin Nutr. 2002;75(6):993-9

16. Oken E, Gillman MW. Fetal origins of obesity. Obes Res. 2003;11(4):496-506.

17. Tam CH, Wang Y, Luan J, Lee HM, Luk AO, Tutino GE, Tong PC, Ko GT, Ozaki R, Tam WH, et al. Non-linear relationship between birthweight and cardiometabolic risk factors in Chinese adolescents and adults. Diabetic medicine: a journal of the British Diabetic Association. 2015;32(2):220-5.

18. Bandaru P, Shankar A. Association between plasma leptin levels and diabetes mellitus. Metab Syndr Relat Disord. 2011;9(1):19-23.

19. Flier JS. Clinical review 94 : What's in a name? In search of leptin's physiologic role. J Clin Endocrinol Metab. 1998;83(5):1407-13.

20. Jaquet D, Gaboriau A, Czernichow P, Levy-Marchal C. Relatively low serum leptin levels in adults born with intra-uterine growth retardation. Int J Obes Relat Metab Disord. 2001;25(4):491-5.

21. Melo AS, Bettiol H, Silva AA, Rosa-e-Silva AC, Cardoso VC, Reis RM, Ferriani RA, Barbieri MA, Vieira CS. Small for gestational age babies are not related to changes in markers of adipose tissue dysfunction during reproductive age. Early Hum Dev. 2014;90(5):231-5.

22. Jaquet D, Leger J, Tabone MD, Czernichow P, Lévy-Marchal C. High serum leptin concentrations during catch-up growth of children born with intrauterine growth retardation. J Clin Endocrinol Metab. 1999;84(6):1949-53.

23. Bieswal F, Ahn MT, Reusens B, Holvoet P, Raes M, Rees WD, Remacle C. The importance of catch-up growth after early malnutrition for the programming of obesity in male rat. Obesity. 2006;14(8):1330-43.

24. Guan H, Arany E, van Beek JP, Chamson-Reig A, Thyssen S, Hill DJ, Yang K. Adipose tissue gene expression profiling reveals distinct molecular pathways that define visceral adiposity in offspring of maternal proteinrestricted rats. Am J Physiol Endocrinol Metab. 2005;288(4):E663-73.

25. Couillard C, Mauriège $P$, Imbeault $P$, Prud'homme D, Nadeau A, Tremblay A, Bouchard C, Després JP. Hyperleptinemia is more closely associated with adipose cell hypertrophy than with adipose tissue hyperplasia. Int J Obes Relat Metab Disord. 2000;24(6):782-8.

26. Schultz NS, Broholm C, Gillberg L, Mortensen B, Jorgensen SW, Schultz HS, Scheele C, Wojtaszewski JF, Pedersen BK, Vaag A. Impaired leptin gene expression and release in cultured preadipocytes isolated from individuals born with low birth weight. Diabetes. 2014;63(1):111-21.

27. Young GA, Woodrow G, Kendall S, Oldroyd B, Turney JH, Brownjohn AM, Smith MA. Increased plasma leptin/fat ratio in patients with chronic renal failure: a cause of malnutrition? Nephrol Dial Transplant. 1997;12(11):2318-23.

28. Baidal JAW, Locks LM, Cheng ER, Blake-Lamb TL, Perkins ME, Taveras EM. Risk factors for childhood obesity in the first 1000 days: a systematic review. Am J Prev Med. 2016. doi:10.1016/j.amepre.2015.11.012.

29. Palatianou ME, Simos YV, Andronikou SK, Kiortsis DN. Long-term metabolic effects of high birth weight: a critical review of the literature. Horm Metab Res. 2014;46(13):911-20.

30. Wells JC, Chomtho S, Fewtrell MS. Programming of body composition by early growth and nutrition. Proc Nutr Soc. 2007;66(3):423-34.

31. Ferreira RJ, Marques-Vidal PM. Prevalence and determinants of obesity in children in public schools of Sintra, Portugal. Obesity. 2008;16(2):497-500. 
32. Reilly JJ, Armstrong J, Dorosty AR, Emmett PM, Ness A, Rogers I, Steer C, Sherriff A. Early life risk factors for obesity in childhood: cohort study. BMJ. 2005;330(7504):1357.

33. Ruiz-Narváez EA, Palmer JR, Gerlovin H, Wise LA, Vimalananda VG, Rosenzweig $\mathrm{LL}$, Rosenberg L. Birth weight and risk of type 2 diabetes in the black women's health study: does adult BMI play a mediating role? Diabetes Care. 2014;37(9):2572-8.

34. Cameron AJ, Spence AC, Laws R, Hesketh KD, Lioret S, Campbell KJ. A review of the relationship between socioeconomic position and the early-life predictors of obesity. Curr Obes Rep. 2015;4(3):350-62.

35. Bellone S, Rapa A, Petri A, Zavallone A, Strigini L, Chiorboli E, Ciardi L, Aguzzi A, Bona G. Leptin levels as function of age, gender, auxological and hormonal parameters in 202 healthy neonates at birth and during the first month of life. J Endocrinol Invest. 2004;27(1):18-23.

36. Chiesa C, Osborn JF, Haass C, Natale F, Spinelli M, Scapillati E, Spinelli A, Pacifico L. Ghrelin, leptin, IGF-1, IGFBP-3, and insulin concentrations at birth: is there a relationship with fetal growth and neonatal anthropometry? Clin Chem. 2008;54(3):550-8.

37. Weyer C, Funahashi T, Tanaka S, Hotta K, Matsuzawa Y, Pratley RE, Tataranni PA. Hypoadiponectinemia in obesity and type 2 diabetes: close association with insulin resistance and hyperinsulinemia. J Clin Endocrinol Metab. 2001:86(5):1930-5.

38. Jaquet D, Deghmoun S, Chevenne D, Czernichow P, Lévy-Marchal C. Low serum adiponectin levels in subjects born small for gestational age: impact on insulin sensitivity. Int J Obes. 2006;30(1):83-7.

39. Challa AS, Evagelidou EN, Cholevas VI, Kiortsis DN, Giapros VI, Drougia AA, Andronikou SK. Growth factors and adipocytokines in prepubertal children born small for gestational age: relation to insulin resistance. Diabetes Care. 2009;32(4):714-9.

40. Boyne MS, Thompson DS, Osmond C, Fraser RA, Thame MM, Taylor-Bryan C, Soares-Wynter S, Forrester TE. The effect of antenatal factors and postnatal growth on serum adiponectin levels in children. J Dev Orig Health Dis. 2013;4(4):317-23.

41. Tamakoshi K, Yatsuya H, Wada K, Matsushita K, Otsuka R, Sugiura K, Kondo T, Toyoshima H. Low birth weight is associated with reduced adiponectin concentration in adult. Ann Epidemiol. 2006;16(9):669-74.

42. Law CM, Barker DJ, Osmond C, Fall CH, Simmonds SJ. Early growth and abdominal fatness in adult life. J Epidemiol Community Health. 1992;46(3):184-6.

43. Eriksson JG, Kajantie E, Lampl M, Osmond C. Trajectories of body mass index amongst children who develop type 2 diabetes as adults. J Intern Med. 2015;278(2):219-26.

44. Araujo de Franca GV, Lucia Rolfe ED, Horta BL, Gigante DP, Yudkin JS, Ong $\mathrm{KK}$, Victora CG. Associations of birth weight, linear growth and relative weight gain throughout life with abdominal fat depots in adulthood: the 1982 Pelotas (Brazil) birth cohort study. Int J Obes. 2016;40(1):14-21.
45. Araujo de Franca GV, Restrepo-Mendez MC, Loret de Mola C, Victora CG. Size at birth and abdominal adiposity in adults: a systematic review and meta-analysis. Obes Rev. 2014;15(2):77-91.

46. Demerath EW, Reed D, Choh AC, Soloway L, Lee M, Czerwinski SA, Chumlea WC, Siervogel RM, Towne B. Rapid postnatal weight gain and visceral adiposity in adulthood: the Fels Longitudinal Study. Obesity. 2009;17(11):2060-6.

47. Rolfe Ede L, Loos RJ, Druet C, Stolk RP, Ekelund U, Griffin SJ, Forouhi NG, Wareham NJ, Ong KK. Association between birth weight and visceral fat in adults. Am J Clin Nutr. 2010;92(2):347-52.

48. Kajantie E, Osmond C, Barker DJ, Forsén T, Phillips DI, Eriksson JG. Size at birth as a predictor of mortality in adulthood: a follow-up of 35,0000 person-years. Int J Epidemiol. 2005;34(3):655-63.

49. Kurajoh M, Koyama H, Kadoya M, Naka M, Miyoshi A, Kanzaki A, KakutaniHatayama M, Okazaki H, Shoji T, Moriwaki Y, et al. Plasma leptin level is associated with cardiac autonomic dysfunction in patients with type 2 diabetes: HSCAA study. Cardiovasc Diabetol. 2015;14:117.

50. Vavruch C, Länne T, Fredrikson M, Lindström T, Östgren CJ, Nyström $\mathrm{FH}$. Serum leptin levels are independently related to the incidence of ischemic heart disease in a prospective study of patients with type 2 diabetes. Cardiovasc Diabetol. 2015;14:62.

51. Visentin S, Grumolato F, Nardelli GB, Di Camillo B, Grisan E, Cosmi E. Early origins of adult disease: low birth weight and vascular remodeling. Atherosclerosis. 2014;237(2):391-9.

52. Johnsson IW, Haglund B, Ahlsson F, Gustafsson J. A high birth weight is associated with increased risk of type 2 diabetes and obesity. Pediatr Obes. 2015;10(2):77-83.

53. Andersson EA, Pilgaard K, Pisinger C, Harder MN, Grarup N, Faerch K, Poulsen P, Witte DR, Jorgensen T, Vaag A, et al. Type 2 diabetes risk alleles near ADCY5, CDKAL1 and HHEX-IDE are associated with reduced birthweight. Diabetologia. 2010;53(9):1908-16.

54. Freathy RM, Bennett AJ, Ring SM, Shields B, Groves CJ, Timpson NJ, Weedon MN, Zeggini E, Lindgren CM, Lango H, et al. Type 2 diabetes risk alleles are associated with reduced size at birth. Diabetes. 2009:58(6):1428-33.

55. Mueller NT, Duncan BB, Barreto SM, Chor D, Bessel M, Aquino EM, Pereira MA, Schmidt MI. Earlier age at menarche is associated with higher diabetes risk and cardiometabolic disease risk factors in Brazilian adults: Brazilian longitudinal study of adult health (ELSA-Brasil). Cardiovasc Diabetol. 2014;13:22.

56. Galea S, Tracy M. Participation rates in epidemiologic studies. Ann Epidemiol. 2007;17(9):643-53.

57. Troy LM, Michels KB, Hunter DJ, Spiegelman D, Manson JE, Colditz GA, Stampfer MJ, Willett WC. Self-reported birthweight and history of having been breastfed among younger women: an assessment of validity. Int J Epidemiol. 1996;25(1):122-7.

\section{Submit your next manuscript to BioMed Central and we will help you at every step:}

- We accept pre-submission inquiries

- Our selector tool helps you to find the most relevant journal

- We provide round the clock customer support

- Convenient online submission

- Thorough peer review

- Inclusion in PubMed and all major indexing services

- Maximum visibility for your research

Submit your manuscript at www.biomedcentral.com/submit
BioMed Central 